\title{
An Overview of India Capital Markets
}

\author{
B.K. Muhammed Juman and M.K. Irshad
}

\begin{abstract}
In India, the history of capital markets dates back to the $18^{\text {th }}$ century when East India Company securities traded the country. The present study is largely based on the available secondary data. The statistical data regarding growth of the capital markets was available from various websites. Capital markets help to channelize surplus funds into productive use. Generally, this market trades mostly in long-term securities. The important divisions of the capital market are stock market, bond market and primary, secondary markets. Primary markets deal with the trade of new issues of stocks and other securities, whereas secondary market deals with the exchange of existing or previously-issued securities. Our finding is that during the first and second five year plans, the Government emphasized on the development of agriculture and public undertakings. The Public sector undertaking was healthier than Private undertakings, but shares were not listed in the stock exchange. More over controller of Capital Issue (CCI) closely supervised everything. A number of investors were interested to invest their savings in debentures instead of company deposits. We conclude that Capital markets were not well organized and developed during the British rule. But in the present scenario, we find that Capital markets are well developed after the introduction of SEBI. Through provision of long term loans, the capital market brings about effective functioning of various sectors of the economy. A sound and efficient capital market is one of the most instrumental factors in the economic development of a nation.
\end{abstract}

Keywords--- Capital Markets, Long-term Securities, Stock Exchange, CCI, SEBI

\section{INTRODUCTION}

$\mathrm{H}$ ISTORY of the capital market in India dates back to the 18 century when east India co. Securities was traded in country. Until the end of the $19^{\text {th }}$ century securities trading was unorganized and the main trading centers were Bombay and Calcutta. Indian capital markets are one of the oldest markets in Asia as well as in the world. Under the British Companies Act, the Stock Exchange, Mumbai, came into existence in 1875. It was an unincorporated body of stockbrokers, which started doing business in the city under a banyan tree, in front of the town hall in Bombay. A small group of stock brokers in Bombay joined together in 1875 to form an association called Native Shares and Stock Brokers

B.K. Muhammed Juman, Research Scholar, Bharathiar University, Coimbatore, Darul Birru(H), Puthalam, Malappuram (P.O.), Pin-673639. Email:juman.bk@gmail.com

M.K. Irshad, Research Scholar, Bharathiar University, Coimbatore, Manar Manzil, Thottilangadi (P.O.), Irivetty, Areacode Via, Malappuram, Pin-673639.E-mail:irshadmkmaxmax@gmail.com DOI: 10.9756/BIJIEMS.8017
Association Bombay. The stock exchanges in Calcutta and Ahmadabad also industrial and trading centers came up later. There has been much fluctuation in the stock market on account of the American war and the battles in Europe. Sir Phiroze Jeejeebhoy was dominated the stock market from 1946 to 1980. His word was law and he had a great deal of influence over both brokers and the government. The Bombay stock exchange was recognized in May 1927 under Bombay securities Contract Control Act 1925. The capital market was not well organized and developed during the British rule because the British government was not interested in economic growth of the country. As a result many foreign co. depended on London capital market for fund.

In the post independence period also the size of capital market is small. The planning process started in India in 1951, with importance being given to the formation of institutions and markets The Securities Contract Regulation Act 1956 became the parent regulation after the Indian Contract Act 1872, a basic law to be followed by security markets in India. To regulate the issue of share prices, the Controller of Capital Issues Act (CCI) was passed in 1947. During the first and second five year plan, the Govt emphasis was on the development of the agricultural and public undertakings. The public undertakings were healthier than Pvt. Undertakings in terms of paid up share capital, but shares were not listed on the stock exchange. More over Controller of Capital Issue (CCI) closely supervised everything. These strict regulations demotivated many company. In the 1950's Century textiles, Tata steel co., Kohinoor mills were the favorite script of speculations. As speculation become rampant, the stock market came to be known as Satta Bazar. The decade of 1950 's was also characterized by the establishment of a network for the development of financial institutions like LIC, GIC and state financial corporations.

\section{CAPITAL MARKETS IN INDIA}

Definition: Capital market is a market where buyers and sellers engage in trade of financial securities like bonds, stocks, etc. The buying and selling is undertaken by participants such as individuals and institutions.

Capital market consists of primary markets and secondary markets. Primary markets deal with trade of new issues of stocks and other securities, whereas secondary market deals with the exchange of existing or previously-issued securities. Another important division in the capital market is made on the basis of the nature of security traded, i.e. stock market and bond market.

Capital market deals with medium term and long term funds. It refers to all facilities and the institutional arrangements for borrowing and lending term funds (medium term and long term). The demand for long term funds comes 
from private business corporations, public corporations and the government. The supply of funds comes largely from individual and institutional investors, banks and special industrial financial institutions and Government.

\section{OBJECTIVES OF THE STUDY}

1. To review the process of growth of capital markets, their evolving structure and their functioning through stock exchanges in India.

2. To examine existing technical analysis for investment decision making and to suggest modifications, if any, with special emphasize on recent development after the implementation of New Economic Policy.

3. To examine the evolution of regulatory mechanism for capital market in India.

4. To find out constraints in smooth functioning of capital market.

\section{RESEARCH Methodology}

The present study is largely based on the available secondary data. The statistical data regarding growth of the capital markets was available from various websites, books and journals.

\section{SCOPE OF THE STUDY}

1. Evolution and growth of Indian capital market.

2. Examination of the present trading system with a view to pin point potential improvements.

3. Study of the problems faced by capital markets and suggests suitable remedies.

\section{LIMITATIONS OF THE STUDY}

1. The study is restricted to the evolution of Indian Capital Market only.

2. Lack of proper control over the brokers and sub brokers

3. Absence of the control over the fair of disclosure of financial information.

\section{LITERATURE REVIEW}

Sharma K.S. (1969)[3] has stressed on the need for mobilizing the savings into investment so that the resources are efficiently used for the economic development. 'It is necessary to strengthen those institutions of the capital market which can garner the savings of the people for further investment otherwise; they are likely to be frittered away in unproductive uses. Higher propensity to consume limits the capacity for voluntary savings in the poorer countries. Here, the various institutions of capital market can help in mobilizing saving and channelizing the same into productive ventures.'

Sharma K.S. (1969)[4] goes ahead with an important role of the capital market that is to provide a platform where the demand for and supply of money (borrowers and lenders) come together.

'The success of capital market depends upon the mobilization of savings and their efficient allocation among different sectors of the economy. Mere multiplicity of the institutions will not help to achieve desired object. In the functional organization, missing links require immediate action. The setting up of the auxiliary institutions will further remove the frictional forces which come between borrower and lender.'

Avadhani V.A. (2002)[5] stressed on impact of liberalization on emergence of capital markets in India. The financial sector reforms also led the development of the capital market in India

Avadhani V.A. (2002)[6] has also thrown light on the various controls and systems which are working for effective settlement and delivery. 'The stock exchange surveillance system and their trading control system aim at imposing margins, operate the circuit breakers, impose limits on brokers in respect of any scrips or total for all scrips and convert trade in any scrip to rolling settlement or for spot trading and cash delivery etc. would all be based on the analysis of data'

Bhasin Niti (2004)[7] further puts forward the challenges posed by the globalization before the Indian markets. Here also the author gives importance to the efficiency of the markets. 'A major issue which will influence India's securities markets in future is the challenge of globalization. There is need for greater thought and policy initiative in fully integrating a global perspective in to the plans of firms, exchanges, regulators and policy makers.

Desai Vasant (2005)[8] has briefly explained the development of the Indian capital market. According to him, liberalization of the stock market operations is necessary for the further development of the markets. 'The Indian capital market has developed to a large extent but is still in a process of evaluation. Various measures have been taken to develop a healthy and mature capital market. These measures include liberalization of stock market operations, opening up of the stock exchange membership to financial institutions, encouraging banks and financial institutions to go in for mutual funds. However one more area which requires serious attention is the scope for a multitier market.'

ICFAI University (2005)[9]projects the positive picture of the capital markets in future. Various steps taken by SEBI help in placing investors in a better position. 'Capital markets are projected to become even more liquid, enabling better price discovery in the days to come. SEBI has introduced margin trading which can make Indian capital markets a better place for investors.

Juhi Ahuja (2012)[10] presents a review of Indian Capital Market \& its structure. In last decade or so, it has been observed that there has been a paradigm shift in Indian capital market. The application of many reforms \& developments in Indian capital market has made the Indian capital market comparable with the international capital markets. Now, the market features a developed regulatory mechanism and a modern market infrastructure with growing market capitalization, market liquidity, and mobilization of resources. The emergence of Private Corporate Debt market is also a good innovation replacing the banking mode of corporate finance. However, the market has witnessed its worst time 
with the recent global financial crisis that originated from the US sub-prime mortgage market and spread over to the entire world as a contagion. The capital market of India delivered a sluggish performance.

\section{ROLE AND IMPORTANCE OF CAPITAL MARKET IN INDIA}

Capital market has a crucial significance to capital formation. For a speedy economic development adequate capital formation is necessary. The significance of capital market in economic development is explained below:-

\section{Mobilization of Savings and Acceleration of Capital Formation}

In developing countries like India the importance of capital market is self evident. In this market, various types of securities help to mobilize savings from various sectors of population. The twin features of reasonable return and liquidity in stock exchange are definite incentives to the people to invest in securities. This accelerates the capital formation in the country.

\section{Raising Long - Term Capital}

The existence of a stock exchange enables companies to raise permanent capital. The investors cannot commit their funds for a permanent period but companies require funds permanently. The stock exchange resolves this dash of interests by offering an opportunity to investors to buy or sell their securities, while permanent capital with the company remains unaffected.

\section{Promotion of Industrial Growth}

The stock exchange is a central market through which resources are transferred to the industrial sector of the economy. The existence of such an institution encourages people to invest in productive channels. Thus it stimulates industrial growth and economic development of the country by mobilizing funds for investment in the corporate securities.

\section{Ready and Continuous Market}

The stock exchange provides a central convenient place where buyers and sellers can easily purchase and sell securities. Easy marketability makes investment in securities more liquid as compared to other assets.

\section{Technical Assistance}

An important shortage faced by entrepreneurs in developing countries is technical assistance. By offering advisory services relating to preparation of feasibility reports, identifying growth potential and training entrepreneurs in project management, the financial intermediaries in capital market play an important role.

\section{Reliable Guide to Performance}

The capital market serves as a reliable guide to the performance and financial position of corporate, and thereby promotes efficiency.

\section{Proper Channelization of Funds}

The prevailing market price of a security and relative yield are the guiding factors for the people to channelise their funds in a particular company. This ensures effective utilisation of funds in the public interest.

\section{Provision of Variety of Services}

The financial institutions functioning in the capital market provide a variety of services such as grant of long term and medium term loans to entrepreneurs, provision of underwriting facilities, assistance in promotion of companies, participation in equity capital, giving expert advice etc.

\section{Development of Backward Areas}

Capital Markets provide funds for projects in backward areas. This facilitates economic development of backward areas. Long term funds are also provided for development projects in backward and rural areas.

\section{Foreign Capital}

Capital markets makes possible to generate foreign capital. Indian firms are able to generate capital funds from overseas markets by way of bonds and other securities. Government has liberalised Foreign Direct Investment (FDI) in the country. This not only brings in foreign capital but also foreign technology which is important for economic development of the country.

\section{Easy Liquidity}

With the help of secondary market investors can sell off their holdings and convert them into liquid cash. Commercial banks also allow investors to withdraw their deposits, as and when they are in need of funds.

\section{Revival of Sick Units}

The Commercial and Financial Institutions provide timely financial assistance to viable sick units to overcome their industrial sickness. To help the weak units to overcome their financial industrial sickness banks and FIs may write off a part of their loan.

\section{GROWTH OF CAPITAL MARKET IN INDIA}

After Independence capital market has shown a remarkable progress. The first organised stock exchange was established in India at Bombay in 1875. When the Securities Contracts (Regulation) Act 1956 was passed, only 7 Stock exchanges Viz. Mumbai, Ahmadabad, Kolkata, Chennai, Delhi, Hyderabad and Indore were started.

Table 1: Chart Showing the Growth of Capital Market

\begin{tabular}{|l|c|c|}
\hline End of December & $1975-76$ & $2013-14$ \\
\hline i) Stock Exchanges (No.) & 8 & 25 \\
\hline ii) Market Value of Capital ( in Crore) & 3,273 & $16,98,428$ \\
\hline iii) Capital Issues (Rs. in Crore) & 98 & 60,502 \\
\hline iv) Capital raised as \% of gross domestic & & \\
\hline Saying (\%) & 0.7 & 7.0 \\
\hline
\end{tabular}

Source: - Tata Services Ltd., statistiscal outline of India 2005-06.

Ministry of statistics India 2013-14 


\section{Factors CONTRIBUting to THE DEVELOPMENT OF CAPITAL MARKET}

\section{Growth of Development Banks and Financial Institutions}

For providing long term funds to industry, the government set up Industrial Finance Corporation in India (IFCI) in 1948. This was followed by a number of other development banks and institutions like the Industrial Credit and Investment Corporation of India (ICICI) in 1955, Industrial Development Bank of India (IDBI) in 1964, Industrial Reconstruction Corporation of India (IRCI) in 1971, Foreign Investment Promotion Board in 1991, Over the Counter Exchange of India (OTCEI) in 1992 etc. In 1969, 14 major commercial banks were nationalised. Another 6 banks were nationalised in 1980. These financial institutions and banks have contributed in widening and strengthening of capital market in India.

\section{Setting up of SEBI}

The Securities Exchange Board of India (SEBI) was set up in 1988 and was given statutory recognition in 1992.

\section{Credit Rating Agencies}

Credit rating agencies provide guidance to investors / creditors for determining the credit risk. The Credit Rating Information Services of India Limited (CRISIL) was set up in 1988 and Investment Information and Credit Rating Agency of India Ltd. (ICRA) was set up in 1991. These agencies are likely to help the development of capital market in future.

\section{Growth of Mutual Funds}

The mutual funds collect funds from public and other investors and channelise them into corporate investment in the primary and secondary markets. The first mutual fund to be set up in India was Unit Trust of India in 1964. In 2007-08 resources mobilised by mutual funds were Rs. 1, 53,802 crores.

\section{Increasing Awareness}

During the last few years there has been increasing awareness of investment opportunities among the public. Business newspapers and financial journals (The Economic Times, The Financial Express, Business India, and Money etc.) have made the people aware of new long-term investment opportunities in the security market.

\section{Growing Public Confidence}

A large number of big corporations have shown impressive growth. This has helped in building up the confidence of the public. The small investors who were not interested to buy securities from the market are now showing preference in favor of shares and debentures. As a result, public issues of most of the good companies are now over-subscribed many times.

\section{Legislative Measures}

The government passed the companies Act in 1956. The Act gave powers to government to control and direct the development of the corporate enterprises in the country. The capital Issues (control) Act was passed in 1947 to regulate investment in different enterprises, prevent diversion of funds to non-essential activities and to protect the interest of investors. The Act was replaced in 1992.

\section{Growth of Underwriting Business}

The growing underwriting business has contributed significantly to the development of capital market.

\section{Development of Venture Capital Funds}

Venture capital represents financial investment in highly risky projects with a hope of earning high returns After 1991, economic liberalisation has made possible to provide medium and long term funds to those firms, which find it difficult to raise funds from primary markets and by way of loans from FIs and banks.

\section{Growth of Multinationals (MNCs)}

The MNCs require medium and long term funds for setting up new projects or for expansion and modernisation. For this purpose, MNCs raise funds through loans from banks and FIs. Due to the presence of MNCs, the capital market gets a boost.

\section{Growth of Entrepreneur}

Since 1980s, there has been a remarkable growth in the number of entrepreneurs. This created more demand for short term and long term funds. FIs, banks and stock markets enable the entrepreneurs to raise the required funds. This has led to the growth of capital market in India.

\section{Growth of Merchant Banking}

The credit for initiating merchant banking services in India goes to Grindlays Bank in 1967, followed by Citibank in 1970. Apart from capital issue management, merchant banking divisions provide a number of other services including provision of consultancy services relating to promotion of projects, corporate restructuring etc.

\section{REFORMS AND DEVELOPMENTS IN CAPITAL MARKET SINCE 1991}

The government has taken several measures to develop capital market in post-reform period, with which the capital market reached new heights. Some of the important measures are

\section{Securities and Exchange Board Of India (SEBI)}

SEBI became operational since 1992. It was set with necessary powers to regulate the activities connected with marketing of securities and investments in the stock exchanges, merchant banking, portfolio management, stock brokers and others in India. The objective of SEBI is to protect the interest of investors in primary and secondary stock markets in the country.

\section{National Stock Exchange (NSE)}

The setting up to NSE in 1992 is a landmark in Indian capital markets. At present, NSE is the largest stock market covering 364 cities and towns across the country. Trading on NSE can be done throughout the country through the network of satellite terminals (fully automated screen-based trading system). NSE has introduced inter-regional clearing facilities. 


\section{Dematerialisation of Shares}

Demat of shares has been introduced in all the shares traded on the secondary stock markets as well as those issued to the public in the primary markets. Even bonds and debentures are allowed in demat form. The advantage of demat trade is that it involves Paperless trading.

\section{Screen Based Trading}

The Indian stock exchanges were modernised in 90s, with Computerised Screen Based Trading System (SBTS), It cuts down time, cost, risk of error and fraud and there by leads to improved operational efficiency. The trading system also provides complete online market information through various inquiry facilities.

\section{Investor Protection}

The Central Government notified the establishment of Investor Education and Protection Fund (IEPF) with effect from 1st Oct. 2001: The IEPF shall be credited with amounts in unpaid dividend accounts of companies, application moneys received by companies for allotment of any securities and due for refund, matured deposits and debentures with companies and interest accrued there on, if they have remained unclaimed and unpaid for a period of seven years from the due date of payment.

\section{Rolling Settlement}

Rolling settlement is an important measure to enhance the efficiency and integrity of the securities market. Under rolling settlement all trades executed on a trading day (T) are settled after certain days $(\mathrm{N})$. This is called $\mathrm{T}+\mathrm{N}$ rolling settlement. Since April 1, 2002 trades are settled' under $\mathrm{T}+3$ rolling settlement. In April 2003, the trading cycle has been reduced to $\mathrm{T}+2$ days. The shortening of trading cycle has reduced undue speculation on stock markets.

\section{The Clearing Corporation of India Limited (CCIL)}

The CCIL was registered in 2001, under the Companies Act, 1956 with the State Bank of India as the Chief Promoter. The CCIL clears all transactions in government securities and repos and also Rupee / US \$ forex spot and forward deals All trades in government securities below Rs. 20 crores would be mandatorily settled through CCIL, white those above Rs. 20 crores would have the option for settlement through the RBI or CCIL.

\section{The National Securities Clearing Corporation Limited (NSCL)}

The NSCL was set up in 1996. It has started guaranteeing all trades in NSE since July 1996. The NSCL is responsible for post-trade activities of NSE. It has put in place a comprehensive risk management system, which is constantly monitored and upgraded to pre-expect market failures.

\section{Trading in Central Government Securities}

In order to encourage wider participation of all classes of investors, including retail investors, across the country, trading in government securities has been introduced from January 2003. Trading in government securities can be carried out through a nationwide, anonymous, order-driver, screen-based trading system of stock exchanges in the same way in which trading takes place in equities.

\section{Credit Rating Agencies}

Various credit rating agencies such as Credit Rating Information services of India Ltd. (CRISIL - 1988), Investment Information and credit Rating Agency of India Ltd. (ICRA - 1991), etc. were set up to meet the emerging needs of capital market. They also help merchant bankers, brokers, regulatory authorities, etc. in discharging their functions related to debt issues.

\section{Accessing Global Funds Market}

Indian companies are allowed to access global finance market and benefit from the lower cost of funds. They have been permitted to raise resources through issue of American Depository Receipts (ADRs), Global Depository Receipts (GDRs), Foreign Currency Convertible Bonds (FCCBs) and External Commercial Borrowings (ECBs). Further Indian financial system is opened up for investments of foreign funds through Non-Resident Indians (NRIs), Foreign Institutional investors (FIls), and Overseas Corporate Bodies (OCBs).

\section{Mutual Funds}

Mutual Funds are an important avenue through which households participate in the securities market. As an investment intermediary, mutual funds offer a variety of services / advantages to small investors. SEBI has the authority to lay down guidelines and supervise and regulate the working of mutual funds.

\section{Internet Trading}

Trading on stock exchanges is allowed through internet, investors can place orders with registered stock brokers through internet. This enables the stock brokers to execute the orders at a greater pace.

\section{Buy Back of Shares}

Since 1999, companies are allowed to buy back of shares. Through buy back, promoters reduce the floating equity stock in market. Buy back of shares help companies to overcome the problem of hostile takeover by rival firms and others.

\section{Derivatives Trading}

Derivatives trading in equities started in June 2000. At present, there are four equity derivative products in India Stock Futures, Stock Options, Index Futures, and Index Options.

Derivative trading is permitted on two stock exchanges in India i.e. NSE and BSE. At present in India, derivatives market turnover is more than cash market.

\section{SECURITIES AND EXCHANGE BoARD OF INDIA (SEBI)}

The concept of stock markets came to India in 1875, when Bombay Stock Exchange (BSE) was established as 'The Native Share and Stockbrokers Association', a voluntary nonprofit making association.

Stocks of various companies are listed on stock exchanges. Presently there are 25 stock markets In India. The Bombay Stock Exchange (BSE), the National Stock Exchange (NSE) 
and the Calcutta Stock Exchange (CSE) are the three large stock exchanges. There are many small regional exchanges located in state capitals and other major cities. Presently Nifty and Sensex are moving around to 5900 and 19600 (July 2013). All activities of Indian stock market are regulated and controlled by SEBI.

SEBI was established as a non-statutory board in 1988 and in 12 April 1992 it was made a statutory body. The main objectives of SEBI are

1) To protect the interest of investors.

2) To bring professionalism in the working of intermediaries in capital markets (brokers, mutual funds, stock exchanges, demat depositories etc.).

3) To create a good financial climate, so that companies can raise long term funds through issue of securities (shares and debentures).

4) To file complaints in courts and to notify its regulations without prior approval of government.

5) To regulate issue of capital and transfer of securities.

6) To impose monetary penalties on various intermediaries and other participants for a specified range of violations.

\section{POWERS AND FUnCTIONS OF SEBI}

\section{Restriction on Insider Trading}

SEBI restricts insider trading activity. It prohibits dealing, communication or counselling on matters relating to insider trading. SEBI's regulation states that no insider (connected with the company) shall - either on his own behalf or on behalf of any other person, deal in securities of a company listed on any stock exchange on the basis of any unpublished price sensitive information.

\section{Regulates Stock Brokers Activities}

SEBI has also laid down regulations in respect of brokers and sub-broker. No brokers or sub-broker can buy, sell or deal in securities without being a registered member of SEBI. It has also made compulsory for brokers to maintain separate accounts for their clients and for themselves. They must also have their books audited and audit reports filed with SEBI.

\section{Regulates Merchant Banking}

SEBI has laid down regulations in respect of merchant banking activities in India. The regulations are in respect of registration, code of conduct to be followed, and submission of half-yearly results and so on.

\section{Dematerialisation of Shares}

Demat of shares has been introduced in all the shares traded on secondary stock markets as well as those issued to public in primary markets. Even bonds and debentures are allowed in demat form.

\section{Guidelines on Capital Issues}

SEBI has framed necessary guidelines in connection with capital issues. The guidelines are applicable to :- First Public Issue of New Companies, First Public Issue by Existing Private / Closely held Companies, Public Issue by Existing Listed Companies.

\section{Regulates Working of Mutual Funds}

SEBI regulates the working of mutual funds. SEBI has laid down rules and regulations that are to be followed by mutual funds. SEBI may cancel the registration of a mutual fund, if it fails to comply with the regulations.

\section{Monitoring of Stock Exchanges}

To improve the working of stock markets, SEBI plays an important role in monitoring stock exchanges. Every recognised stock exchange has to furnish to SEBI annually with a report about its activities during the previous year.

\section{Secondary Market Policy}

SEBI is responsible for all policy and regulatory issues for secondary market and new investments products. It is responsible for registration and monitoring of members of stock exchanges, administration of some of stock exchanges and monitoring of price movements and insider trading.

\section{Investors Grievances Redressal}

SEBI has introduced an automated complaints handling system to deal with investor complaints. It assists investors who want to make complaints to SEBI against listed companies.

\section{Institutional Investment Policy}

SEBI looks after institutional investment policy with respect to domestic mutual funds and Foreign Institutional Investors (FIIs). It also looks after registration, regulation and monitoring of FIls and domestic mutual funds.

\section{Takeovers and Mergers}

To protect the interest of investors in case of takeovers and mergers SEBI has issued a set of guidelines. These guidelines are to be followed by corporations at the time of takeovers and mergers.

\section{CONCLUSION}

The history of capital markets in India dates back to almost 200 years. The history of the Indian capital markets and the stock market, in particular can be traced back to 1861 when the American Civil War began. The opening of the Suez Canal during the 1860s led to a tremendous increase in exports to the United Kingdom and United States. Several companies were formed during this period and many banks came to the fore to handle the finances relating to these trades. Indian capital markets are one of the oldest markets in Asia as well as in the world. There are instances in the early nineteenth century which tell us about the presence of capital market in India. In 1830 's business on corporate stocks and shares in bank and cotton presses took place in Mumbai. It started with only six brokers and a few entities like banks and cotton presses who traded among themselves in loan securities which laid the foundation of trading in stocks. During these days, East India Company was dominant in Indian market. As the time progressed, the trading was also affected by some external events like World War I and II, American Civil War etc. As the British Empire was ruling India, the direct and indirect effects of the developments: political as well as economical, were also observed in Indian markets. The most popular stock 
exchange in India i.e. BSE was initiated as an association of brokers in 1887.The BSE building, icon of the Indian capital markets, is called P.J. Tower in his memory. The 'Jijibhoy Tower' which is popularly indicated as 'heart of Indian financial market' was formally inaugurated in the year 1899 . Afterwards the cities like Ahmadabad, Kolkata, and Delhi also had stock exchanges. But the real momentum in these stock exchanges was observed after India's independence i.e. after 1947. Relatively smaller cities like Cochin, Pune, Jaipur, Patna, Rajkot, Guwahati also had the stock exchanges which were established after the independence. After independence i.e. 1947 in Indian capital markets, an element of speculation crept into the market. Increased cost of public issues and isolated nature of stock exchanges were the other problems which emerged in the post-independence phase.

\section{REFERENCE}

[1] S Kevin,' Security Analysis and Portfolio Management", PHI Learning Pvt Ltd,New Delhi,Pp.32- 35.(Sep2010), ISBN: 978.8120329638

[2] Dr. S Gurusamy,'Merchant Banking and Financial Services", Vijay Nicole Imprints Pvt Ltd, Chennai, Pp.127-147.(2007), ISBN: 818209190X

[3] Sharma K.S.(1969) "The Institutional Structure of Capital Markets in India” - Sterling Publishers (Pvt.)Ltd. Jullundur City, p.14.

[4] Sharma K.S. (1969) "The Institutional Structure of Capital Markets in India"- Sterling Publishers (Pvt.)Ltd. Jullundur City p.275.

[5] Avadhani V.A.(2002) "Investment Management", Himalaya Publishing, p. 81

[6] Avadhani V.A.(2002) "Investment Management", Himalaya Publishing,p.236-250.

[7] Bhasin Niti (2004) "Indian Financial System: Reforms, Policies and Prospects", New Century Publications, New Delhi(2004), p.144-145.

[8] Desai Vasant (2005) "The Indian Financial System and Development", Himalaya Publishing House, Pp.195.

[9] ICFAI University (2005) "An Overview of Capital Markets" Investment Banking and Financial Services- Vol. I, ICFAI University Press, Pp.205.

[10] Juhi Ahuja (2012), "Indian Capital Market: An Overview with Its Growth" VSRD International Journal of Business \&Management Research Vol. 2 (7), pp. 386-399.

[11] Deepak R Raste,' Capital Market in India: Reforms and Regulations", New Century Publicaition, New Delhi, Pp. 5-10(july2011), ISBN:817 7082868

[12] Asheesh Pandey," Capital Market \& Financial System in India", New Century Publication, New Delhi,Pp.3-7(Jan 2014),ISBN:8177083651

[13] 13.Barua S K,Raghunathan V and Varma Jayanth.R.(1994)"Research on the Indian capital Market: a Review". Indian Institute Ahamadabad, (Feb).Pp.1.

[14] Barua S K \& Raghunathan V (1986), "Inefficiency of the Indian Capital Market", Vikalpa, Vol. 11,No. 3,(Jul-Sept), p. 225-230.

[15] Barua S K \& Raghunathan V (1987), "Inefficiency and Speculation in the Indian Capital Market", Vikalpa, Vol. 12, No. 3,(Jul-Sept), p. 53-58.

[16] Gupta Ramesh(1992a), "Development of the Capital Market in India: A Regulatory Perspective", Working Paper No. 997, (Jan-Mar), Indian Institute of Management, Ahmedabad.

[17] Ms Anju Bala(2013),'Indian Stock market Review of Literature", TRANS Asian Journal of Marketing \&Management Research Vol.2 Issue 7,Pp.68. July 2013, ISSN 2279-0667

[18] Ministry of statistics and planning programme 2013-14

[19] www.sebi.gov.in/investor

[20] www.investmentz.co.in/research 